\title{
Does China-AFTA Impact on Inequality and Employment Rate of Indonesia: Comparing with Other ASEAN Countries
}

\author{
Caria Ningsih
}

\begin{abstract}
China-ASEAN Free Trade Area is the third largest free trade area in terms of nominal GDP and first largest in term of population. Some economists argue that free trade increases the standard of living by concept of comparative advantage and large scale economies. Meanwhile, some others argue that free trade allows leading countries to exploit poor countries; destroy local industryies; and limits social standards and labor. By available data analysis of Gini Index and unemployment rate of ASEAN's countries and China, it can be interpreted that after China-AFTA implementation in 2010, there was increasing income inequality in Indonesia, while in the rest ASEAN countries was remain constant and decrease. Furthermore, the unemployment rate of most of ASEAN countries and China has remain constant from 2010-2012. It means that China-AFTA implementation did not reduce the unemployment rate. Overall, the result analysis of this paper is still ambiguous to describe the impact of free trade toward inequality of regional development between China and ASEAN countries, particularly Indonesia.
\end{abstract}

Index Terms - China-AFTA, inequality, Indonesia.

\section{INTRODUCTION}

The ASEAN Free Trade Area (AFTA) agreement was signed on 28 January 1992 in Singapore. When the AFTA agreement was originally signed, ASEAN had six members, namely, Indonesia, Brunei, Malaysia, Philippines, Thailand and Singapore. Vietnam joined in 1995, Laos and Myanmar in 1997 and Cambodia in 1999. AFTA now comprises the ten countries of ASEAN. All the four late comers were required to sign the AFTA agreement in order to join ASEAN, but were given longer time frames in which to meet AFTA's tariff reduction obligations. The primary goals of AFTA seek to increase ASEAN's competitive edge as a production base in the world market through the elimination, within ASEAN, of tariffs and non-tariff barriers; and attract more foreign direct investment to ASEAN. The primary mechanism for achieving the goals given above is the scheme, which established a schedule for phased initiated in 1992 with the self-described goal to increase the region's competitive advantage as a production base geared for the world market.

Manuscript received February 25, 2017; revised May 3, 2017.

C. Ningsih is with the Indonesia University of Education, Indonesia; and he is also with Hankuk University of Foreign Studies, South Korea (e-mail: caria.ningsih@gmail.com, caria.ningsih@hufs.ac.kr).
AFTA does not use a common external tariff on imported goods. Each ASEAN member may impose tariffs on goods entering from outside ASEAN based on its national schedules. However, for goods originating within ASEAN, ASEAN members apply a tariff rate of 0 to 5 percent (the more recent members of Cambodia, Laos, Myanmar and Vietnam, also known as CMLV countries, were given additional time to implement the reduced tariff rates). This is known as the Common Effective Preferential Tariff (CEPT) scheme.

ASEAN members have the option of excluding products from the CEPT in three cases: 1) Temporary exclusions; 2) Sensitive agricultural products; 3) General exceptions. Temporary exclusions refer to products for which tariffs will ultimately be lowered to $0-5 \%$, but which are being protected temporarily by a delay in tariff reductions. Sensitive agricultural products include commodities such as rice. ASEAN members have reduce tariff levels to $0-5 \%$ until 2010, then move to the General exceptions address to products which an ASEAN member considers necessary for the protection of national security, public morals, the protection of human, animal or plant life and health, and protection of articles of artistic, historic, or archaeological value. ASEAN members have agreed to enact zero tariff rates on virtually all imports by 2010 for the original signatories, and 2015 for the CMLV countries. ASEAN has component agreements on goods (ASEAN Trade in Goods Agreement (ATIGA)); services (ASEAN Framework Agreement on Services (AFAS)) and investment (Comprehensive Investment Agreement (ACIA)). Moreover, ASEAN has FTAs with: Australia and New Zealand; China; India; Japan; and Korea [1].

The goods part of ASEAN's FTA with China was increased in 2010. On 4 November 2002 the previous framework agreement was signed in Phnom Penh, Cambodia. It had been followed by the intention to establish a free trade area agreement among China and ten ASEAN member countries by 2010. The free trade area become effective on 1 January 2010.

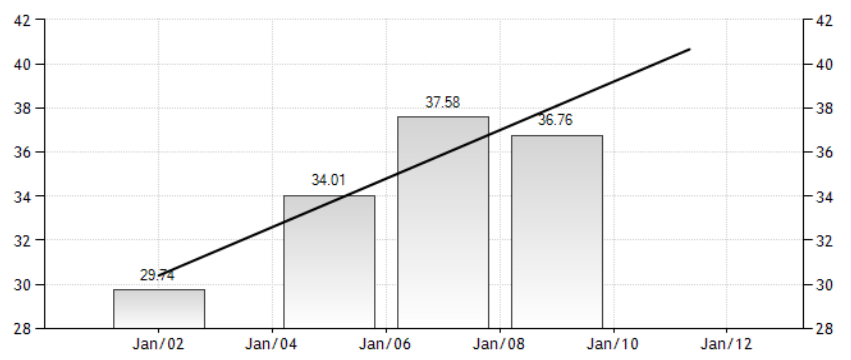

Fig. 1. Gini Index of Indonesia Period 2002 - 2010. 
In case of Indonesia, trade liberalization has a direct impact on the welfare and prosperity of some Indonesia people. From the Fig. 1 shows the positive trend of inequality development in Indonesia from 2002-2010 by the increasing of Gini Index's of Indonesia.

The Gini index of Indonesia was 36.76 in 2009, according to a World Bank report, published in 2010 [2]. Gini index measures the extent to which the distribution of income (or, in some cases, consumption expenditure) among individuals or households within an economy deviates from a perfectly equal distribution. A Lorenz curve plots the cumulative percentages of total income received against the cumulative number of recipients, starting with the poorest individual or household. The Gini index measures the area between the Lorenz curve and a hypothetical line of absolute equality, expressed as a percentage of the maximum area under the line Thus a Gini index of 0 represents perfect equality, while an index of 100 implies perfect inequality. Fig. 1 includes a historical data chart and forecasts for Gini index in Indonesia.

Inequality that occurred in Indonesia is caused by many factors. As in Myrdal theory [3] mentioned that regions advanced experience accumulated a competitive advantage over those areas develops. The development will give effect to other areas if the area experiencing growth. The spread impact in underdeveloped countries ruled by turning effect. Ironically, market forces and free trade tends to hamper export potential underdeveloped countries because their products are removed by the product states forward. In which the cooperation between developed countries with state will led to enhance inequality in terms of economic development.

Globalization address to how connected or open a country with the other countries. It is mostly present by liberalization of trade. The common used proxies in globalization is trade ratio and foreign direct investment (FDI). Many researchers for many decade have been interesting to discuss the potential impact of globalization on economic and social wellbeing. The Heckcher-Ohlin-Samuelson (HOS) model (1919) [4] predicts that openess will be beneficial for unskilled labor in developing countries.

One of the most leading trends in the global economy in the past three decades has been a rising within-country income inequality in many developed and developing countries [5]. During the 1980s and 1990s, there was considerable concern about the possible role of globalization in contributing to rising income inequality in developed countries [6]. Based on the implication by the standard Stolper-Samuelson (SS) theorem that growing trade can have large effects on income distribution, and can easily leave less-skilled workers worse off.

There are many studies on the effect of trade on income inequality since the Hecksher-Ohlin (HO) model and the SS theorem, a possible linkage between Free Trade Agreements (FTAs) and income inequality has received little attention and has not been studied thoroughly. The FTA provides a unique window into the effects of the free trade. As an agreement between two countries, the FTA is a relatively clean policy experiment, untainted by macroeconomic shocks or financial crises [7].

Furthermore, Goldberg and Pavcnik [8] emphasized that the relationship between globalization and inequality is ambiguous. Several studies have found that globalization show different policy implication. Demirgüc-Kunt and Levine [9] has found that globalization can reduce inequality through financial integration. Jaehwa Lee dan Jongsung Kim [10] and Suryahadi [11] on their part have found that globalization effect inequality in mixed effect. In the other hand, Fallon and Lucas [12] and Choi [13] noted that financial integration and FDI effect the enhancing in inequality.

It is important to examine the importance problem of inequality in economic development and trade liberalization, in order to know the strategies to counter and reduce inequality rate in ASEAN member countries, particularly Indonesia. Based on the background issues that have been described, it interesting to analyze Does China-AFTA Impact on Inequality and Employment Rate of Indonesia: Comparing with other ASEAN Countries?

\section{METHOD}

This paper has used descriptive analytical method on Gini index and unemployment of ASEAN's countries and China after and before CAFTA implementation in 2010 to investigate the relationship of CAFTA with inequality and employment rate.

Gini index measures the extent to which the distribution of income (or, in some cases, consumption expenditure) among individuals or households within an economy deviates from a perfectly equal distribution. A Lorenz curve plots the cumulative percentages of total income received against the cumulative number of recipients, starting with the poorest individual or household. The Gini index measures the area between the Lorenz curve and a hypothetical line of absolute equality, expressed as a percentage of the maximum area under the line. Thus a Gini index of 0 represents perfect equality, while an index of 100 implies perfect inequality.

The employment rate is a measure of the prevalence of unemployment and it is calculated as a percentage by dividing the number of unemployed individuals by all individuals currently in the labor force.

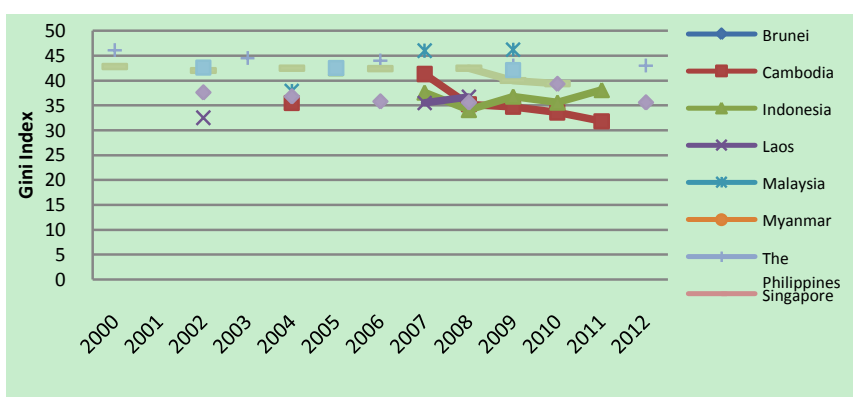

Fig. 2. Gini Index of ASEAN countries and chinaperiod 2000-2012.

\section{RESULT AND DISCUSSION}

\section{A. Gini Index Analysis}

This page includes a series data chart for Gini index in ASEAN's countries and China since 2000 -2012. It can be seen from the Fig. 2 that from 2000 until 2012 most of ASEAN countries, such as Cambodia, Malaysia, Myanmar, 
Philippine, Thailand and Vietnam experienced decreasing in their Gini Index, meanwhile Indonesia's Gini Index shows a positive trends. In the other hand, China's Gini Index was relative constant, approximately at 42 . Interestingly, after CAFTA implementation in 2010, it is only Indonesia's Gini Index that increased from 35, 6 in 2010 become 38, 1 in 2011, while the other ASEAN countries show the opposite scenes. By the limited data, it can be interpreted that inequality economic Indonesia increases when CAFTA has been implemented, but it has not happened in the rest of ASEAN member countries.

Indonesia is the largest national economy in Southeast Asia. It has a market-based economy in which the government plays a significant role by owning more than 164 state-owned enterprises. The government administers prices on several basic goods, including fuel, rice, and electricity. Inequality that occurred in Indonesia is caused by many factors. Through some discussion, these study also resume the factor behind the rise income inequality in case Indonesia are, first, inequality opportunity in education and health that effected by a tight fiscal policy after the Asia crisis. Second, unequal jobs. Third, high wealth concentration. The last, low of endurance among poor. In overall, those factors are influenced by globalization, free trade, market-oriented reform and privatization.

However, a number of new mechanisms have been explored through which trade can affect (and usually increase) income inequality. These include within-industry effects due to heterogeneous firms; effects of off-shoring of tasks; effects on incomplete contracting; and effects of labor-market frictions. A number of these mechanisms have received substantial empirical support [5].

However, trade liberalization characterized by AFTA in Indonesia (2003) is expected to reduce the imbalance of development between region, and as government's efforts in realizing effective and controlled economic growth in Indonesia. By the limited data, we can not adjust that the inequality development region has closely related with CAFTA.

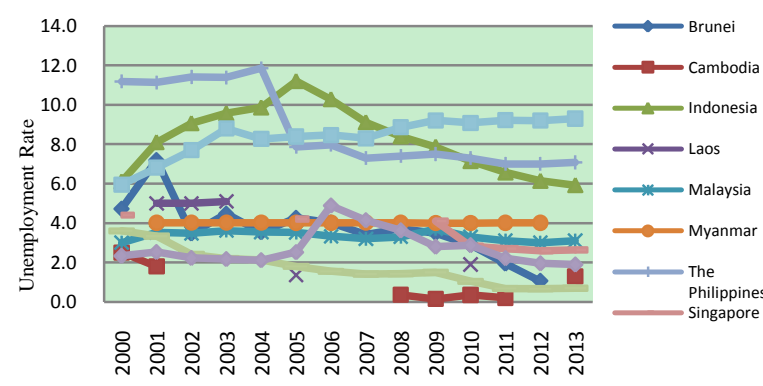

Fig. 3. Unemployment Rate of ASEAN Countries and China Period 2000-2013.

\section{B. Unemployment Rate Analysis}

Fig. 3 describes unemployment rate of ASEAN's Country and China from 2000-2013 [14]. It can be seen from the figure that the unemployment rate of ASEAN's countries and China fluctuatively decline from 2000 until 2010. Furthermore, between 2010 and 2013, most of the ASEAN countries' unemployment rate was remained constant; meanwhile The Phillippine's unemployment rate was increasing slightly. In the other hand, the China's unemployment rate has remained increasing before and after CAFTA implementation. Regarding to the condition, it can be interpreted that China-AFTA implementation in 2010, has not effected to reduce the unemployment rate in ASEAN Countries.

\section{CONCLUSION}

By available data analysis of Gini Index and unemployment rate of ASEAN's countries and China, it can be intrepreted that after China-AFTA implementation in 2010, there was increasing in Indonesia income inequality, while the rest ASEAN member remain constant. Inequality in Indonesia is caused by many factors that need more investigation.

Furthermore, the unemployment rate of most of ASEAN countries were remained constant from 2010-2013. It means that China-AFTA implementation has not reduced the unemployment rate in ASEAN countries, even in China.

Overall, the result analysis of this paper is still ambiguous to describe the impact of free trade toward inequality of regional development between ASEAN countries and China, because the data of this paper are limited to perfomance the economic conditions of the ASEAN countries and China completely. Thus, it need more research that able to analyze the extent to which the free trade Areas impact on economic inequality in the ASEAN countries and China.

\section{ACKNOWLEDGEMENT}

The authors wish to acknowledge the guidance of Associate Proffesor Nury Effendi.

\section{REFERENCES}

[1] ASEAN Secretariat, "A blueprint for growth ASEAN economic community 2015: Progress and key achievements," The ASEAN Secretariat, Jakarta, Indonesia, 2015.

[2] World Development Indicator. [Online]. Available: http://data.worldbank.org/data-catalog-development-indicators

[3] P. Iswanto, "The strategy of growth and economic development in Indonesia," International Journal of Science and Qualitative Analysis, vol. 1, no. 2, pp. 29-32, 2015.

[4] P. R. Krugman, M. Obstfeld, and M. J. Melitz, "International economcs theory and policy, ninth edition," Pearson Education Limited, pp. 110-134, 2012.

[5] A. Harrison, J. McLaren, and M. S. McMillan, "Recent findings on trade and inequality," International Food Policy Research Institute, NBER Paper No.16425, 2010.

[6] OECD, "Income inequality and growth: The role of taxes and transfers," OECD Economics Department Policy Notes, no. 9, January 2012.

[7] Trefler and Daniel, "The Long and short of the Canada-U.S. free trade agreement," American Economic Review, vol. 94, no. 4, pp. 870-895, 2004.

[8] Goldberg and Pavcnik, "Distributional effects of globalization in developing countries," NBER Working Paper No. 12885, Cambridge. 2007.

[9] Demirgüc-Kunt and Levine, "Finance, inequality and the poor," The World Bank, Washington, USA, 2007.

[10] J. Lee and J. Kim, "Do free trade agreements affect income inequality? An empirical investigation," JEL classification: E24, F16, F23, May 2014.

[11] Suryahadi and A. Yadi, "Globalization and wage inequality in Indonesia, a CGE analysis," East-West Cetre Working Papers, Economic Series, No.26. 2001

[12] Fallon and Lucas, "The impact of financial crisis on labor market, household incomes and povesty: A review evident," The World Bank Research Observer, vol.17, no. 1 (Spring, 2002), The World Bank, pp. 21-24, 2002. 
[13] Choi, "Does foreign direct investment affect domestic income inequality?" EconPaper, vol. 13, issue 12, pp. 811-814, 2006.

[14] Asia Development Bank, Statistic Database. [Online]. Available: https://www.adb.org/data/statistics

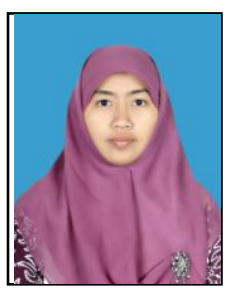

C. Ningsih was born in Bandung, Indonesia on January 31, 1980. She got the bachelor degree at development economic studies major, Economic Department of Padjadjaran University, Bandung, Indonesia. Then, master of economics at Graduate School of Padjadjaran University, Bandung, Indonesia. Recently, she is a student of PhD Program of international trade and commerce major at Graduate School of International and Areas Studies (GSIAS) of South Korea.
She is a state lecturer at Social Sciences Education Department of Indonesia University of Education, Bandung, Indonesia. Before being a doctoral program, her last job was a coordinator of Research and Society Submission in her major office. Previous publication are: Shariah Concepts On Strategic Industries Development (Bandung, Indonesia: Proceeding of International Conference and Call Paper of Toward Policy and Business Based on Islamic Economics Principles, 2013); Foreigners Interest for Using Subway in Seoul, South Korea (Seoul, South Korea; Proceeding of The 78th TOSOK International Tourism Conference, 2015); and Competitiveness of Indonesia Tourism Industry in Facing ASEAN Economic Community (Bandung, Indonesia: IHTC2016 and ISOT2016 Proceeding, 2016). Her current interest research is about Asia Economic Integration.

Ms. Ningsih has worked as a tutor of Training Education for Teacher Profession in Tourism at National Education Ministry. She was one of a speaker on Tourism Joint Seminar Nara Prefectural University and Indonesia University of Education, Kyoto, Japan 2012. She has worked as a committee of International Seminar of Tourism (ISOT) 2016. 